\title{
AUTHIGENIC SILICEOUS MINERALS IN THE TREMADOC GRAPTOLITIC ARGILLITE OF ESTONIA
}

\author{
Aadu LOOG ${ }^{a}$ and Valter PETERSELL ${ }^{b}$
}

\author{
a Tartu Ulikooli Geoloogia Instituut (Institute of Geology, University of Tartu), \\ Vanemuise 46, EE-2400 Tartu, Eesti (Estonia) \\ b Eesti Geoloogiakeskus (Geological Survey of Estonia), Pikk 67, EE-0001 Tallinn, \\ Eesti (Estonia)
}

Presented by A. Raukas

Received 16 May 1994, accepted 27 September 1994

\begin{abstract}
Graptolitic argillite contains in addition to rockforming minerals (hydromicas, chlorite, clastic quartz of pelitic fraction) and accessory minerals also authigenic ones. Numerous clay minerals, carbonates, sulphides, and siliceous minerals are authigenic. Siliceous minerals form lenticular or pocket-shaped laminae on several levels in the eastern part of the distribution area of graptolitic argillite that contains spicules of siliceous sponges and siliceous dioxide.

Siliceous dioxide occurs in various forms: as amorphous silicon, opal, chalcedony, and authigenic quartz. Opal may occur in the composition of spicules and partly also of globules. Chalcedony is found as aggregates with a fibrous composition and collomorphic structure. It forms spherulites, bundles, and incrustites around clastic grains and pyrite crystals and on the walls of cavities. There are metacolloidal pellets, plats, and rods of irregular shape among the chalcedonic globules. Edgings and coatings of authigenic quartz are abundant.

The siliceous laminae were formed during the early phase of diagenesis. Amorphous silica dioxide was replaced by chalcedony and then by quartz during the diagenesis. Their formation became possible thanks to a short-term input of a large amount of siliceous material into the basin. The leaching of silica as colloidal solutions in the denudation area was not sufficient for this. It is supposed that hydrothermae were a source of silicon. The deep origin of silicon is supported by the high content of several typical hydrothermal elements in the siliceous interlayers.
\end{abstract}

Key words: Ordovician, Baltic region, mineralogy, authigenic siliceous minerals, graptolitic argillite.

Graptolitic argillite is an argillaceous rock enriched with organic matter. Apart from rock-forming (hydromicas, chlorite, clastic quartz of pelitic fraction, and feldspars) and accessory minerals, it contains also authigenic minerals. Numerous carbonates, sulphides, clay, and siliceous minerals are authigenic.

The section of graptolitic argillite, particularly in the eastern part of its distribution area (Fig. 1), shows on several levels the occurrence of lenticular or pocket-shaped siliceous laminae that consist of spicules of siliceous sponges (Müürisepp, 1964). As a rule, the siliceous sponges are related to silt interlayers occurring in argillite. The silt interlayers form on different levels horizontal lenticular laminae, which are a few millimetres to $10 \mathrm{~cm}$ thick and are often thinning out (Fig. 2). During 
the diagenetic recrystallization silicon preserved its volume or even increased it. The clay layers, however, became more compact. This resulted in the formation of pressure structures - the silt laminae bent around siliceous lenses.

The composition and structure of siliceous laminae are complicated. They are mostly composed of white, in places grey due to the presence of admixtures (clay minerals, pyrite, organic matter, etc.), porous, soft silica $\left(\mathrm{SiO}_{2}\right)$ and clastic quartz. Actually they are quartzose silt (Table $1)$, which contains spicules of siliceous sponges and fine-globular silica. In places the latter may predominate, forming collomorphic pure siliceous nodules.

Apart from clastic quartz and authigenic silica, the siliceous laminae contain clay minerals, pyrite, marcasite, calcite, feldspars, and rare accessory minerals. Fragmentary rhabdosomes of graptolites and brachiopod valves can be found less frequently.

Also light-brown phosphatic ooids, which have split by dehydration, have been recorded. Ooids often occur on the immediate contact of silt and argillite.

Silica is found in different mineral forms: amorphous silicon, opal, chalcedony, and authigenic quartz. They, in turn, may have various modes of occurrence.

Opal has been recorded in the composition of the spicules partly also in globules. The spicules of siliceous sponges are white conical pods up to $3 \mathrm{~mm}$ in length and with diameters of a few hundredths or tenths of millimetre. The cavities of the spicules often contain pyrite crystals (Fig. 3) .

Chalcedony occurs as fibrous collomorphic aggregates. The fibres form spherulites, bundles, and coatings around clastic grains and pyrite crystals as well as on the walls of the cavities (Fig. 4). The chalcedony globules constitute a white porous mass of porcelain lustre, which contains irregular sharp-edged metacolloidal pellets, white plates, and rods of chalcedony.

In places the globules are covered with iron oxides, clay minerals, or a pyrite film. The contact of the silt lamina and graptolitic argillite often shows a layer of chalcedony (a more recent formation). Inside the globules pyrite crystals, quartz grains, and also clay minerals are frequent.

Clastic quartz grains are often surrounded by an authigenic quartz edging. More rarely the quartz grains are entirely coated with authigenic quartz. Such coatings may occur as regenerated cement.

It is very difficult to determine the time of the formation of the regenerated coatings. The reason is that their optical orientation coincides with that of clastic grains and together they form a whole. Authigenic quartz may occur as solitary crystals $(0.1-1.0 \mathrm{~mm}$ in diameter) or druses.

The formation of the siliceous interlaminae in graptolitic argillite could have taken place in the following way. Benthic siliceous sponges dwelled on the silty bottom of the basin. The basin experienced an abundant influx of siliceous compounds, which the sponges used for building their skeletons. After the death of the sponges, their spicules deposited in situ or accumulated elsewhere. Diagenesis resulted in the compaction of the sediments, which caused changes in the volume of pores and the composition of porewater. Alterations took place in rockforming minerals (clay minerals, quartz, feldspars). Selective dissolution of clastic and authigenic minerals, input and removal of the material, colloidal dehydration, and recrystallization occurred. All this led to the formation of authigenic minerals. 


\begin{tabular}{|c|c|c|}
\hline & L & 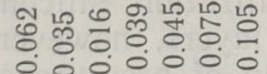 \\
\hline & Oొ & 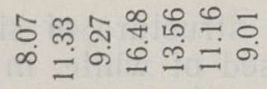 \\
\hline & 豆 & 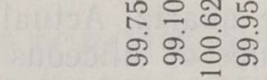 \\
\hline & (- & 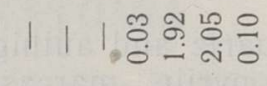 \\
\hline$\therefore$ & $0_{\infty}^{\infty}$ & 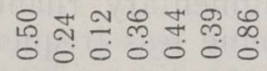 \\
\hline bo & $\overrightarrow{\dot{0}}$ & 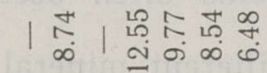 \\
\hline$\frac{\overline{0}}{\frac{0}{0}}$ & Oֵ & 官 \\
\hline E & $\begin{array}{l}\text { O } \\
\text { Z }\end{array}$ & 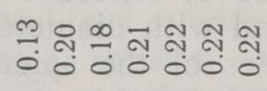 \\
\hline$\frac{\pi}{\frac{\pi}{2}}$ & $\sum_{\substack{0 \\
\infty}}$ & 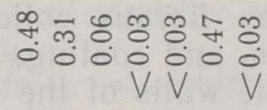 \\
\hline : & ○్ & 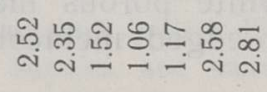 \\
\hline$\stackrel{\text { I }}{ \pm}$ & $\stackrel{0}{\Sigma}$ & 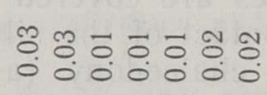 \\
\hline$\stackrel{5}{\stackrel{5}{5}}$ & $\overbrace{}^{\infty}$ & 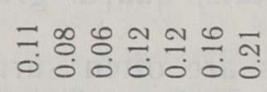 \\
\hline $\bar{E}$ & $\begin{array}{l}\text { O } \\
\text { II }\end{array}$ & 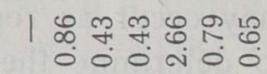 \\
\hline 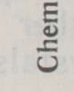 & 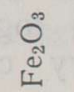 & 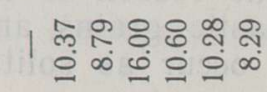 \\
\hline & 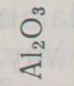 & 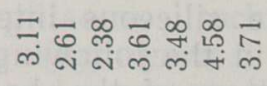 \\
\hline & in & 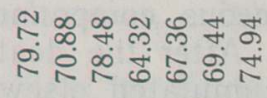 \\
\hline & 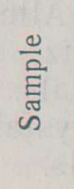 & 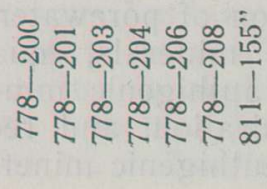 \\
\hline
\end{tabular}



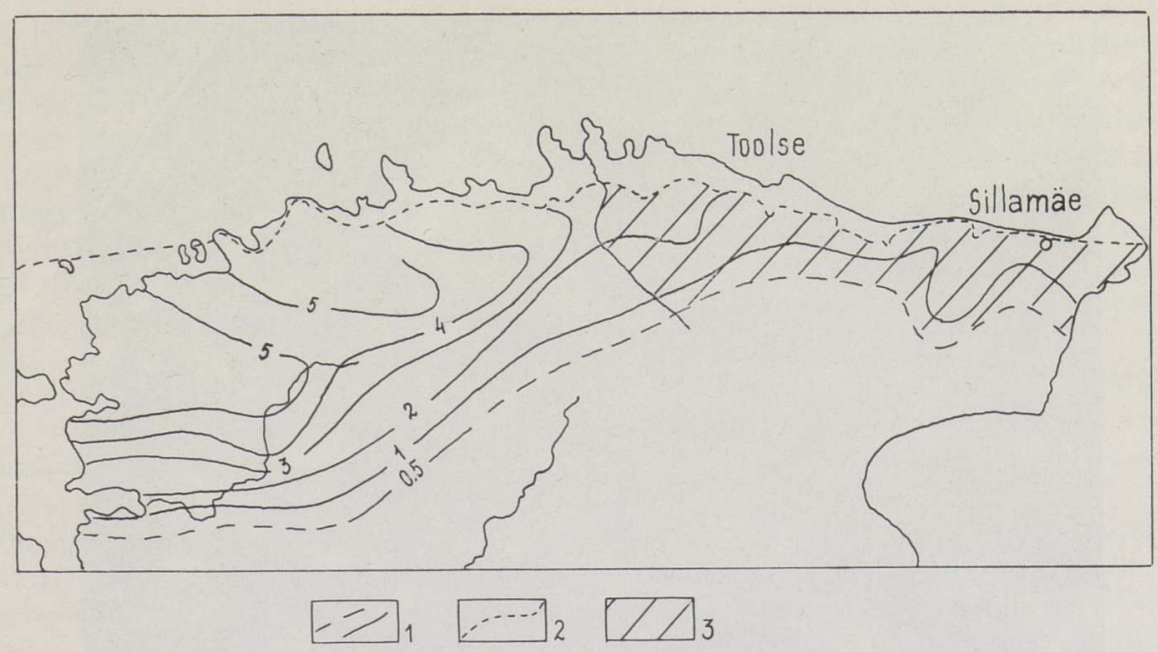

Fig. 1. Distribution of Tremadoc graptolitic argillite in Estonia.

1 isopahite; 2 erosion line; 3 area where siliceous laminae occur.

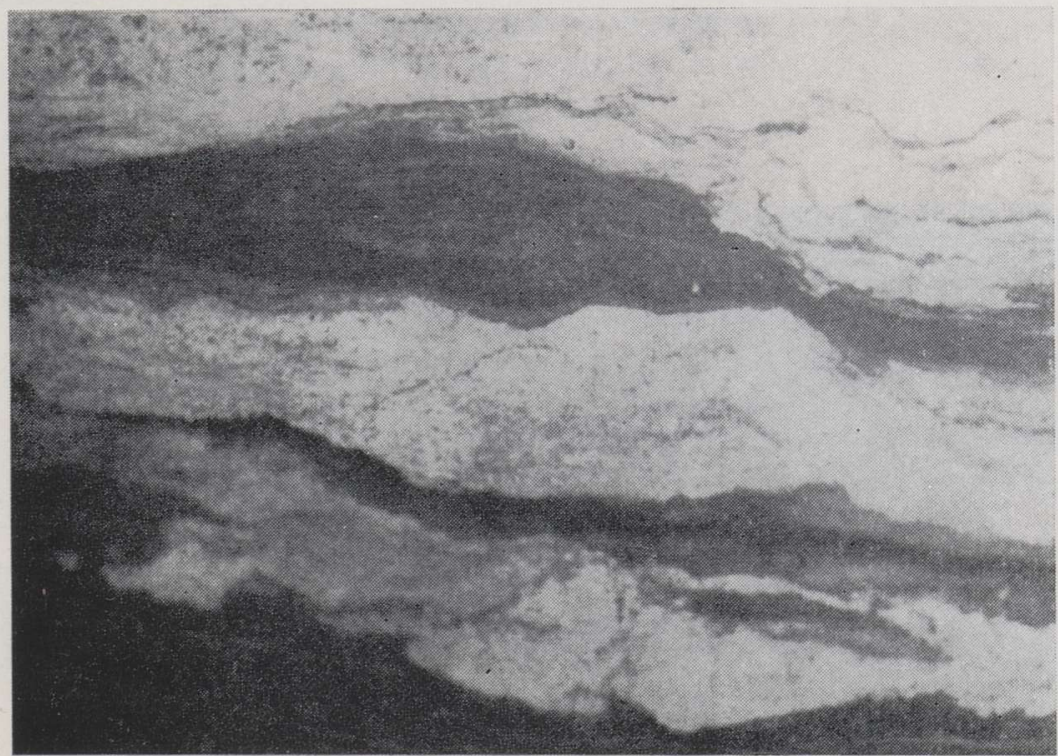

Fig. 2. Lenticular structure of graptolitic argillite. Black denotes graptolitic argillite; grey, siltstone (silt) interlayers; and white, amorphous siliceous material. Toolse borehole No. 778 . 


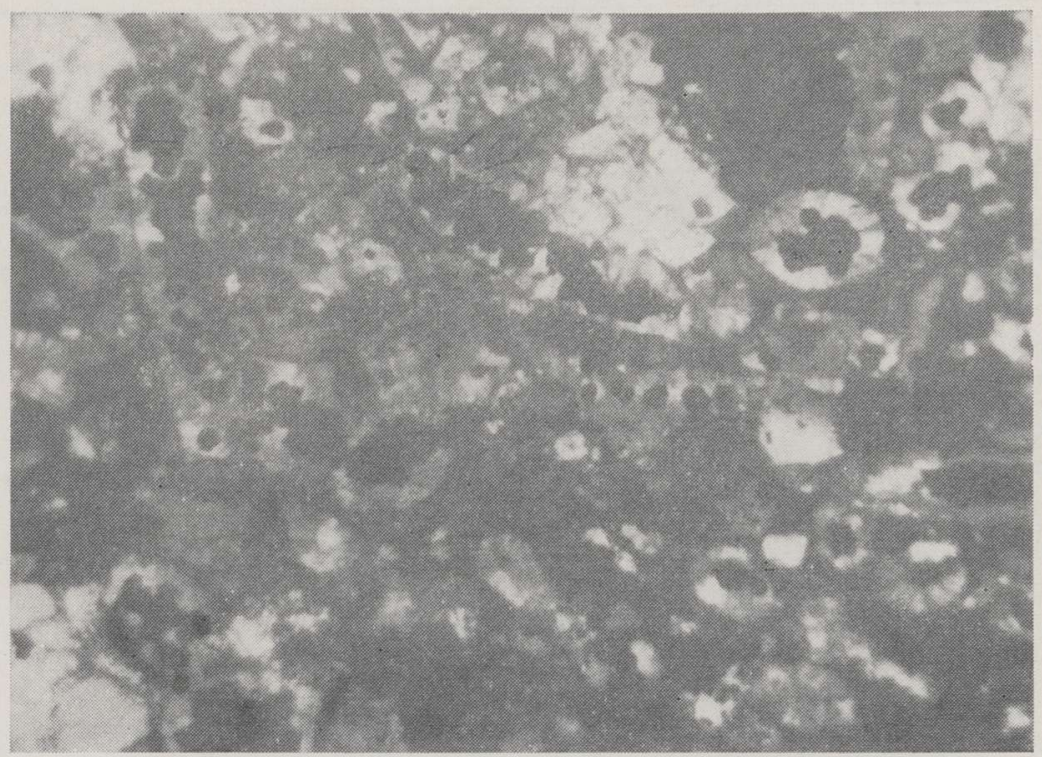

Fig. 3. Initially the spicules of siliceous sponges consisted of opal, which turned into chalcedony during diagenesis. Grey denotes chalcedony; black, pyrite; and white, calcite. Thin section D-1303, Toolse boreho'e No. 695 , depth $18.82 \mathrm{~m} . \times 70$, with analyser. The longitudinal section of spicules is well seen. In the cavities of the spicules and chalcedony globules distinct pyrite crystals occur.

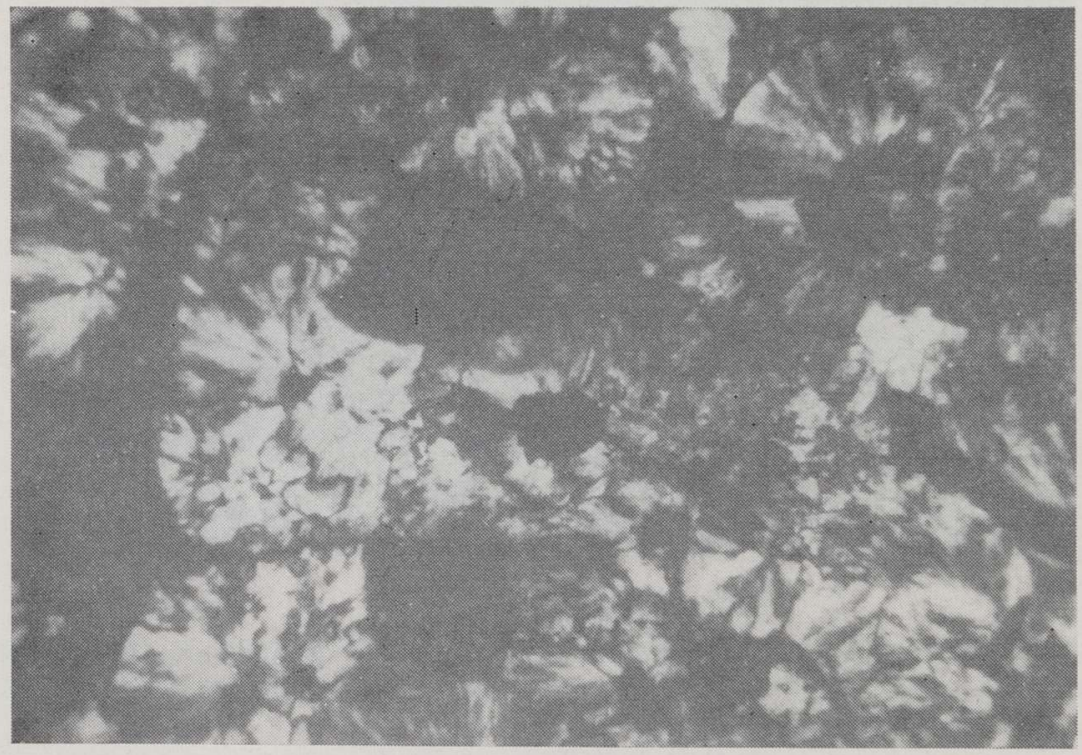

Fig. 4. Chalcedony spherulites in the siliceous laminae. Thin section D-1307, Toolse borehole No. 695 , depth 19.24 m. $\times 90$, with analyser. 
The spicules were subjected to partial dissolution already during their deposition on the bottom of the basin and their later burial, i.e. at the early phase of diagenesis. It was a slow and complicated process, as initially the spicules were covered with a film of organic matter, which protected them from dissolution and bacteria. Dissolution took place in the medium with a high $\mathrm{pH}$ value, therefore the intrastratal solution was unsaturated. Together with the formation of silica gels, organogenous opal in the spicules was transformed into cryptocrystalline chalcedony. The lowering of $\mathrm{pH}$ values in porewater caused the coagulation of silica gels, which had entered it in various ways. Opal globules, whose dehydration caused the appearance of chalcedony, were formed.

Table 2

X-ray analysis of silicified graptolitic argillite from Toolse

\begin{tabular}{l|r|r|r|r|r|r|r|r|r|r}
\hline \multirow{2}{*}{ Samples } & \multicolumn{7}{|c|}{ Contents of minerals, mass \% } \\
\cline { 2 - 10 } & Qz & Py & Mr & Do & Ka & Or & Ill & Gy & Ja & Cl \\
\hline $811-147$ & 51 & 25 & 5 & 9 & 4 & 2 & 0 & 2 & 2 & 6.8 \\
$811-154$ & 66 & 12 & 4 & 0 & 0 & 4 & 10 & 1 & 3 & 6.8 \\
$778-200$ & 69 & 10 & 3 & 3 & 1 & 4 & 7 & 1 & 2 & 6.1 \\
$778-201$ & 64 & 11 & 5 & 0 & 0 & 5 & 11 & 2 & 3 & 5.5 \\
$778-203$ & 71 & 16 & 2 & 0 & 0 & 5 & 0 & 0 & 6 & 6.0 \\
$778-204$ & 69 & 15 & 2 & 0 & 0 & 2 & 8 & 1 & 3 & 5.1 \\
$778-206$ & 60 & 8 & 4 & 0 & 0 & 7 & 17 & 1 & 3 & 6.7 \\
$778-208$ & 38 & 49 & 8 & 0 & 0 & 5 & 0 & 0 & 1 & 6.9
\end{tabular}

Qz - quartz, Do - dolomite, Ill - illite (or sericite), Py - pyrite, Ka - calcite, Gy - gypsum, $\mathrm{Mr}$ - marcasite, Or - orthoclase, Ja - jarosite, $\mathrm{Cl}$ - crystallinity of quartz (10-point scale).

Analyst: J. Aruväli.

Crystallinity of quartz

$1-8$ order of samples in Table 2

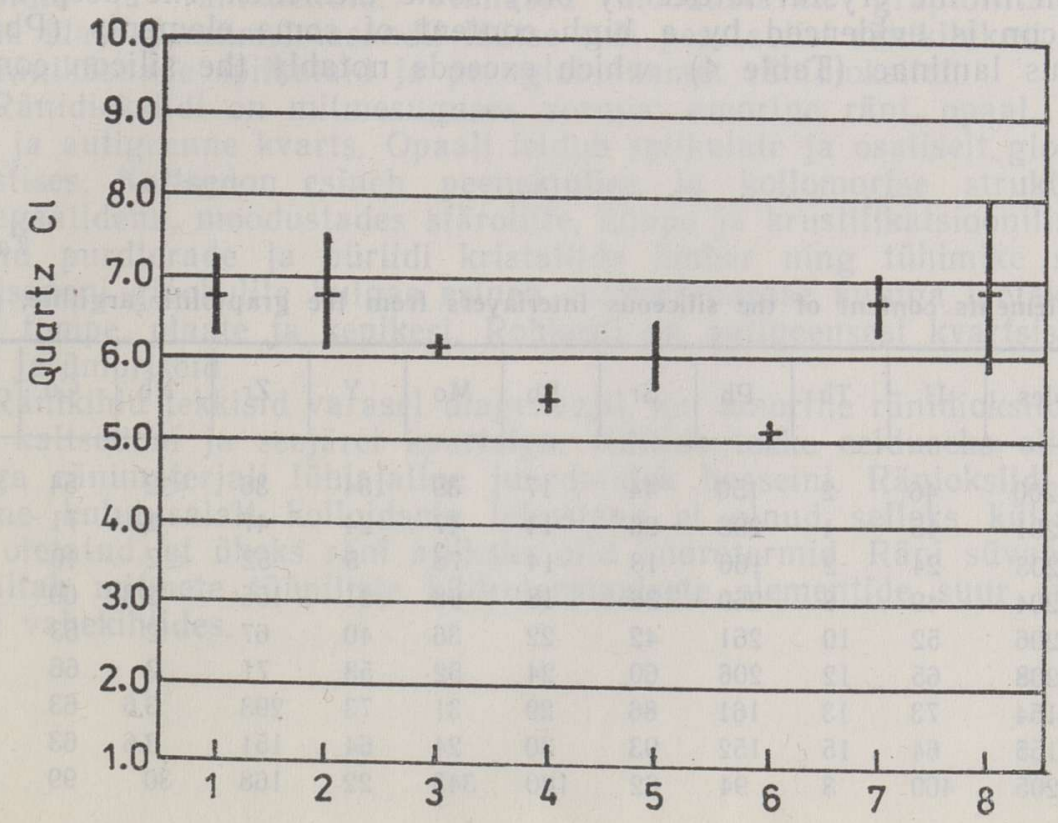


X-ray diffractometric studies (Tables 2,3 ) have also revealed the replacement of amorphous silica (opal) by chalcedony and then by quartz during diagenesis. This is evidenced by the crystallinity of quartz amounting to 5.1-6.9 (in a 10-point scale). The transition opal-chalcedony-quartz, which has been a very long process, is also observed in spicules and globules.

The formation of siliceous laminae at the early phase of diagenesis and an abundant silica input are also confirmed by the presence of distorted pressure structures in graptolitic argillite. The development of the collomorphic structure refers to rhythmic removal of silica from the intrastratal solution. The moving of gel particles towards a certain centre was also recorded. The late diagenesis was characterized by a further redistribution of silica. In siltstone interbeds siliceous regenerated cement was locally formed.

The development of such siliceous laminae was possible under the conditions of a short-term input of abundant siliceous material into the basin and a negligible deposition of other components. The deposition rate of fine-dispersed mud in the Tremadoc was low: from $1 \mathrm{~mm}$ per 1000 years (Lindström, 1971) to $3 \mathrm{~mm}$ per 1000 years (Thickpenny, 1984).

The leaching of silica into colloidal solutions was insufficient in the denudation area. Siliceous biogenous and chemogenous sedimentation was obviously connected with local input of hydrothermae. As mentioned above, siliceous laminae occur only in the eastern part of the distribution area of graptolitic argillites, where the contents of several (U, V, Mo, etc.) elements are elevated. The extensive hydrothermal input of microelements in the Tremadoc has found increasingly more confirmation (Петерселль et al., 1987).

The dissolved compounds moved from the water of the sedimentary basin into intrastratal solutions, where they were caught mostly by organic compounds and clay minerals during diagenetic processes. It appears that in the diagenetic varieties of siliceous minerals no concentration of elements occurred. Compared to the host rock, the siliceous laminae contain less microelements (Лоor, 1982). This is partly caused by a small radius of the silicon ion, which permits the replacement of silicium in the crystal lattice by only some elements. The deep origin of silicon is evidenced by a high content of some elements $(\mathrm{Pb})$ in siliceous laminae (Table 4), which exceeds notably the silicon content

Table 4

Microelements content of the siliceous interlayers from the graptolitic argillite, ppm

\begin{tabular}{l|r|r|r|r|r|r|r|r|r|r|r}
\hline Samples & $\mathrm{U}$ & $\mathrm{Th}$ & $\mathrm{Pb}$ & $\mathrm{Sr}$ & $\mathrm{Rb}$ & $\mathrm{Mo}$ & $\mathrm{Y}$ & $\mathrm{Zr}$ & $\mathrm{Nb}$ & $\mathrm{Cu}$ & $\mathrm{Zn}$ \\
\hline $778-200$ & 46 & 2 & 150 & 44 & 17 & 39 & 34 & 36 & $<2$ & 54 & 62 \\
$778-201$ & 45 & 4 & 208 & 26 & 14 & 47 & 24 & 47 & 2 & 71 & 54 \\
$778-203$ & 24 & 2 & 160 & 13 & 14 & 78 & 5 & 52 & $<2$ & 40 & 115 \\
$778-204$ & 49 & 8 & 269 & 36 & 18 & 98 & 31 & 155 & 2.3 & 69 & 69 \\
$778-206$ & 52 & 10 & 261 & 42 & 22 & 36 & 40 & 67 & 2 & 63 & 59 \\
$778-208$ & 65 & 12 & 206 & 60 & 24 & 52 & 53 & 71 & 2 & 66 & 62 \\
$811-154$ & 73 & 13 & 161 & 86 & 29 & 31 & 73 & 293 & 3.6 & 63 & 59 \\
$811-155$ & 64 & 15 & 152 & 93 & 30 & 24 & 64 & 151 & 3.6 & 63 & 46 \\
$778-205$ & 469 & 3 & 94 & 62 & 100 & 343 & 22 & 168 & 30 & 99 & 97
\end{tabular}


in the surrounding graptolitic argillites. (The occurrence of only some metal sulphides refers to the monometallic character of input solutions.)

Graptolitic argillite and siliceous laminae have been subjected to hypergenesis, which is evidenced by the presence of gypsum and jarosite in them (Table 2).

\title{
REFERENCES
}

Lindström, M. 1971. Vom Anfang, Hochstand und Ende eines Epikontinentalmeeres. Geologische Rundschau, 60, 2, 419-438.

Müürisepp, K. 1964. Käsnaläätsedest pakerordi lademes. - Loodusuurijate seltsi aastaraamat, $56,17-24$.

Thickpenny, A. 1984. The sedimentology of the Swedish Alum shales. - In: Stow, D., Piper, D. (eds.). Deep-water Processes and Facies. Oxford, 511-525.

Лоог А. 1982. К геохимии постседиментационного минералообразования в граптолитовых аргиллитах Северной Эстонии. - Уч. зап. Тартуск. ун-та, вып. 527. Tр. по геол., VIII, 44-49.

Петерселль В. Х., Жуков Ф. И., Лоог А. Р., Фомин Ю. А. 1987. Происхождение тремадокских керогенсодержащих алевролитов и аргиллитов Северной Эстонии. - Горючие сланцы, 4/1, 8-13.

\section{RÄNI AUTIGEENSED MINERAALID EESTI TREMADOCI GRAPTOLIITARGILLIITIDES}

\author{
Aadu LOOG, Valter PETERSELL
}

Graptoliitargilliidi koostises esinevad lisaks kivimit moodustavatele (montmoriloniit-hüdrovilgud, kloriit, peliitse fraktsiooni terrigeenne kvarts ning päevakivid) ja aktsessoorsetele mineraalidele veel autigeensed mineraalid. Uustekkelised on paljud savimineraalid, karbonaadid, sulfiidid ja räniühendid. Viimased moodustavad graptoliitargilliidi levila idaosas mitmel tasandil läätse- või pesataolisi ränikihikesi, milles on ränikäsnade spiikulaid ja peenglobulaarset ränidioksiidi.

Ränidioksiidi on mitmesuguses vormis: amorfne räni, opaal, kaltsedon ja autigeenne kvarts. Opaali leidub spiikulate ja osaliselt gloobulite koostises. Kaltsedon esineb peenekiulise ja kollomorfse struktuuriga agregaatidena, moodustades sfäroliite, kimpe ja krustifikatsioonilisi koorikuid purdterade ja püriidi kristallide ümber ning tühimike seintel. Kaltsedoni gloobulite hulgas esineb ebakorrapärase kujuga metakolloidseid tompe, plaate ja kepikesi. Rohkesti on autigeensest kvartsist ääriseid ja ümbriseid.

Ränikihid tekkisid varasel diageneesil, kui amorfne ränidioksiid asendus kaltsedoni ja seejärel kvartsiga. Kihtide tekke eelduseks oli suure hulga ränimaterjali lühiajaline juurdetulek basseini. Ränioksiidi väljakanne kulutusalalt kolloidsete lahustena ei olnud selleks küllaldane. On oletatud, et üheks räni allikaks olid hüdrotermid. Räni süvapäritolu kinnitab mitmete tüüpiliste hüdrotermaalsete elementide suur sisaldus räni vahekihtides. 


\title{
АУТИГЕННЫЕ КРЕМНЕВЫЕ МИНЕРАЛЫ В ТРЕМАДОКСКИХ ГРАПТОЛИТОВЫХ АРГИЛЛИТАХ ЭСТОНИИ
}

\author{
Ааду ЛООГ, Вальтер ПЕТЕРСЕЛЛЬ
}

В состав граптолитовых аргиллитов, кроме породообразующих (монтмориллонит-гидрослюд, хлорита, кварца и полевых шпатов пелитовой фракции) и акцессорных минералов, входят -также аутигенные минералы. К ним относятся новообразования глинистых минералов, карбонатов, сульфидов и кремния. Последние образуют на разных уровнях разреза в восточной части полосы развития граптолитовых аргиллитов линзообразные тела и гнезда с примесью спикул кремневых губок и тонкоглобулярного диоксида кремния.

Диоксид кремния представлен аморфным кремнем, опалом, халцедоном и аутигенным кварцем. Опал входит в состав спикул и глобул. Халцедон представлен тонковолокнистыми агрегатами колломорфной структуры, образующими сферолиты, «пучки» и крустификационные корочки вокруг зерен терригенных минералов и кристаллов пирита, на стенках пустот. Среди глобул халцедона присутствуют метаколлоидные сгустки неравномерной конфигурации, пластинки, палочки. Часто встречаются пленки и каемки аутигенного кварца. Кремневые прослойки образовались на ранней стадии диагенеза, когда аморфный диоксид кремния преобразовался в халцедон и кварц. Предпосылкой тому послужило кратковременное поступление в бассейн осадконакопления большого количества кремневых соединений. Вынос диоксида кремния из области выветривания в виде коллоидных растворов был, по-видимому, недостаточен. Предполагается, что одним из источников кремния были гидротермы. Глубинное происхождение кремния подтверждается высокими содержаниями типичных гидротермальных элементов в кремневых прослойках. 